https://helda.helsinki.fi

\title{
Adjectives as terms
}

\section{Pitkänen-Heikkilä, Kaarina}

2015

Pitkänen-Heikkilä , K 2015 , ' Adjectives as terms ' , Terminology , vol. 21 , no. 1 , pp.

pÿ76 101. https://doi.org/10.1075/term.21.1.04pit

http://hdl.handle.net/10138/322501

https://doi.org/10.1075/term.21.1.04pit

cc_by_nc

acceptedVersion

Downloaded from Helda, University of Helsinki institutional repository.

This is an electronic reprint of the original article.

This reprint may differ from the original in pagination and typographic detail.

Please cite the original version. 
Adjectives as terms

Kaarina Pitkänen-Heikkilä

Department of Finnish, Finno-Ugrian and Scandinavian Studies

University of Helsinki

Post Box 3

00014 University of Helsinki

kaarina.pitkanen@helsinki.fi

This paper discusses terminology in the field of plant morphology, where nearly half of the terms are adjectives. What are adjectives as terms like? How are they differentiated from adjectives in the general language? How should adjectives be treated in terminological description and terminography? For example, the relationship between an adjective and the object it characterizes differs from the relationship between a noun and the object it refers to. For a systematic definition, adjectives have often been changed to nouns in terminological dictionaries: property names derived from adjectives or modifiers of noun phrases. This article argues that such a method is not applicable in plant morphology because, on the one hand, that kind of nouns do not occur in the texts that describe plants and, on the other hand, because of the semantic changes it may cause. The article also proposes some new tools for the description and definition of adjectival terms.

adjectives, property names, definition, botanical term, plant morphology 


\section{Introduction}

This article deals with adjectival terms in terminology work both theoretically and practically. The need to understand adjectives as terms arose during the creation of a new Finnish terminological database (The Bank of Finnish Terminology in Arts and Sciences, BFT). BFT is a database built for maintaining, developing and establishing of Finnish scientific and scholarly terminology. It is based on limited crowdsourcing in the Semantic MediaWiki platform and it is openly accessible for all researchers and citizens. Botany is one of three pilot projects with hundreds of adjective terms which require appropriate definitions. I will open the discussion with the following questions: what is a term and how should it be theoretically described? How should empirically produced linguistic information concerning the appearance and use of terms be taken into account in terminology work? I am a linguist but also familiar with the theory of terminology. My earlier studies have concerned vocabularies of special purposes and term formation in Finnish (Pitkänen 2008, Pitkänen-Heikkilä 2013). This article has been written for terminologists and researchers of terminology and special languages, but it also offers some interesting points of view for linguists. Linguistically, however, adjectives should be studied more systematically and by using the material of the general language as well.

Section 1 introduces the place and theoretical description of adjectives in the theory of terminology, and continues with the instructions given in terminological guidelines for describing and defining adjectives. Finally, I present the material, background and aims of this study. Section 2 examines the adjective category linguistically, and adjectives used as terms in my material consisting of plant morphology. 
Section 3 presents the conventions for defining adjectives traditionally in botany, and particularly in current Finnish floras and botanical glossaries. In section 4 I present my conclusions and recommend some corrections to both the guidelines for terminology work and the theoretical description of terms.

\subsection{The term and its parts of speech}

In the theory of terminology, terms are designations that represent the concepts in special fields. These concepts represent any perceivable or conceivable referents or $o b$ jects in the human mind. The link between the object and the term is made through the concept, an idea based on the semantic triangle of Ogden and Richards. (ISO 704:2009, 2, 22; Ogden \& Richards 1923, 10-12.) Although the objects can be abstract as well as concrete, this description is the most applicable for terms that are nouns, because nouns refer directly to referents; this is contrast to adjectives, whose basic use is to characterize referents.

In texts of special purposes, the property of referents can be described accurately with an adjective phrase, and the relations of referents can be expressed, for example, in adverbials. Adjective phrases and adverbials can be terms as well, although they have a different relation to referents than nouns have. An adjective, for example, characterizes the referent (acute inflammation) while an adverbial tells something about, for example, its state or place (in situ 'in position' hybridization). A verb again tells something about the action of the referent (bacteria assimilate). They all predict something about the referent: properties, classes, relations, spaces and events. Nouns are terms that directly refer to concepts, while adjectives, adverbs and verbs predict 
something about the concept. Thus a term is always not a designation of a concept; it can also be an expression that predicts something about the concept.

In guidelines of terminology work, as well as in terminological research, adjectives and other parts of speech, except for nouns, have often been ignored. Their being terms is not denied, but the various parts of speech have been taken for granted (e.g. Cabré 1998, 87-88; Suonuuti 2001, 32; ISO 704:2009, 23-24). Some explanations for them have been given, however, which have not conformed to the theoretical descriptions of terms, referents and concepts. This has led to adjectives, adverbials and verbs being presented as modifiers of nouns or noun derivatives in the lexicons and glossaries of special domains: anaerobic bacteria, acute inflammation; in situ hybridization; budding, assimilation. If lemmas are like these, they can be defined according to the generally accepted principles of terminology work: as nouns with the help of the name of the superordinate concept (systematic methods of definition in terminology work are introduced, for example, in ISO 704:2009, 23-28). Sager (1990, 63) even implies that "properties, qualities and states - - acquire nominal forms in order to fit the requirements of systematic categories for special reference".

In regard to adjectives, this kind of operation results in complexity, giving rise to the opinion that the adjective class is not an appropriate part of speech for terms. The characteristics of such terms would offer any number of subjects for study, although some related research has been done (e.g. on adjectives Daille 2001, Bae 2006, Compos \& Castells 2010, Pitkänen-Heikkilä 2013; on verbs L'Homme 1998, Castro 2012, Casademont 2014). Furthermore, such research is challenging because the theory of terminology does not offer appropriate methods for it. Since parts of speech 
other than nouns have been phased out of terminological glossaries, collecting material is difficult. Various corpuses nowadays can indeed challenge this but there is regrettably little qualitative research based on such comprehensive material.

It is clear, however, that adjectival terms occur abundantly in certain fields such as chemistry, medicine and botany. Verbs exist in technical fields (e.g. in information technology: to load, to save, to download). Music has adverbs for showing dynamics and tempo (Forte fortissimo 'very loud', Allegro vivace 'lively and fast') - they are terms as well. In fact, these concept systems may contain superordinate concepts that belong to the same part of speech, and through them, terms could be defined purely according to the principles of systematic terminology work (e.g. Allegro vivace vs. Allegro 'fast, quickly and bright'; in botany serrate 'toothed like a saw' vs. toothed 'cut in from the margin').

Thus, the term is not always the designation that directly represents the entity and refers to it; it can also be an expression (adjective, adverb or verb) that characterizes the entity or tells something very essential about it. Such terms can also be crucially important in the concept system. In fact, the nature and existence of properties (qualities, characteristics) have long been studied in philosophy. Aristotle, for example, thought that an entity is disconnected from its properties (substance theory), but later ideas, especially those of David Hume, suggest that entities consist of a bundle of properties and do not exist as independent substances at all (bundle theory) (Robinson 2014). Terminologically, the substance theory actually regards an entity and its properties in terms of ownership while the bundle theory sees them as being in a partwhole relationship. 
1.2. Definition in systematic terminology work

Instructions for terminology work and definition are presented in both guidelines for terminology work and ISO-standards. There are many types of definition, but the most often recommended are intensional definitions, which give the minimal information needed to differentiate a concept from all other concepts; for example, from coordinate concepts. The definition consists of the superordinate concept and the delimiting characteristics. The superordinate concept in a definition situates the concept in its proper context in the concept system (e.g. the tree in a group of plants). (ISO 704:2009, 22.)

Are such instructions suitable for parts of speech other than nouns? Adjectives, verbs and adverbs are usually passed over in the proper guidelines of terminology work. Similarly, they are rarely considered in research. However, it is usually recommended that the head word of a definition be in the same part of speech as the term (ISO 704:2009, 23). One of the basic instructions of definition is the substitution principle (ISO 704:2009, 25), ${ }^{1}$ which means that the definition can replace the term in the text without changing the meaning. This principle is valid for adjectives if they have been defined by another adjective or participle.

Some researchers have recently been interested in the description of concepts in regarding to various concept relations. Faber et al. $(2007,2009)$ introduce the processoriented approach that is based on frame semantics. Although they still have been concerning with nouns, they show up new concept relations besides generic relations

\footnotetext{
${ }^{1}$ The substitution principle is based on Leibniz's ontological principle, identity of indiscernibles, which is known as Leibniz's law today. This principle can be formed like this: "If two objects have all their properties in common then they are one and the same entity."
} 
to the spotlight (e.g. Faber et al. 2009: 10-12). The examination of the various concept relations of a term as well as the context where the term occurs is crucial when forming accurate definitions of adjectival terms as well.

How should adjectives then be defined? If the aim is to form intensional definitions based on generic relations, it can be difficult to find a superordinate concept that exists in the subject field. This is because the adjective terms rarely have other adjective terms as the names of superordinate concepts ${ }^{2}$. Typically, if an adjective is used as a superordinate concept in a definition, it must be a commonly existing adjective in the general language, because other adjectives from the same term system do not exist. Instead of looking for a appropriate adjective it is therefore more useful (and also easier) to name the referent or referents that an adjective describes ${ }^{3}$. Using the name of the referent for the same special purpose also attaches the term to the proper concept system, contrary to using some adjective from the general language in place of the superordinate concept. An essential question is: what is the conceptual relationship between $x$ that has characteristic $y$ and $y$ that is characteristic of $x$ ? It is not a generic genus-species relation, but a property relation, the relationship between the property and the owner of the property.

ISO 704 also includes various alternatives for the definition of adjectives. According to the standard, intensional definitions that represent adjectival designations usually begin with a word or phrase that expresses the position or function of an ob-

\footnotetext{
${ }^{2}$ Sometimes they have; e.g. the botanical terms sahalaitainen $[<$ saha 'saw' + laita 'margin' + ADJ.SUFFIX. -inen; Engl. serrate 'toothed like a saw, with teeth pointing forward'] and nirhalaitainen [nirhata 'to gnaw'; Engl. dentate 'toothed along the margin with the teeth pointing outward'] have a superordinate concept that is hammaslaitainen [hammas 'tooth'; Engl. toothed 'cut in from the margin']).

${ }^{3}$ This should, however, not realise by changing the adjectival terms to noun phrases (as I explain later).
} 
ject; this is often a gerund or present participle (being, occurring, of, relating to, having; e.g. bot. acaulescent 'having no apparent stem above ground'). (ISO 704:2009, 23-24.) These instructions for the definition of adjectives show that the standard does not disagree that adjectives can be terms.

In terminology work, however, it is typical that adjectives are replaced by property names (acute $\rightarrow$ acuteness) or modifiers of noun phrases (anaerobic $\rightarrow$ anaerobic bacteria). That was the situation in the BFT when we ordered the definitions for a small botanical terminology from The Finnish Terminology Centre (TSK): the first question of the terminologist concerned the possibility of changing adjectival terms to noun phrases.

\subsection{Material, background and objects}

In this article, I examine adjective terms in botanical data. My material includes approximately 600 adjective terms in Finnish (501 from plant morphology, 108 from plant ecology) that have been entered into the database of the BFT. The material also includes the definitions of these terms given in the BFT and in the four books introduced below. In addition to this terminological data, I have narrative Finnish material from two Floras and an e-learning environment. It would be interesting to include terms from speech but such material is difficult to collect.

This study is based on data that has been collected from the following writings: Retkeilykasvio (Field Flora of Finland, later RK1998) is a respected scientific Flora listing approximately 300 terms of Finnish plant morphology. Otavan kasvitieto (Illustrated Flora of Britain and Northern Europe, later OKT2005) is a Flora that has 
been directed to the general public. It is originally translated from English and has been modified for the flora of Finland. The vocabulary of 235 terms includes seventynine adjectives. Biologian sanakirja (Dictionary of Biology, later BS2001) is the most comprehensive scientific dictionary of biological Finnish. It includes approximately 1,600 terms of plant biology with a relatively small number of terms that characterize plants (c. 110); most of them are from plant ecology. Terms of plant morphology have mainly been omitted from this dictionary. Flora Nordica (later FN2004) is a respected Nordic Flora that includes multilanguage vocabulary with English definitions. The vocabulary includes terms mainly from plant morphology but also from plant ecology. It includes 488 adjectives and 1,017 nouns. Pinkka is a web-based learning environment for students of biology that has been built at the University of Helsinki since 2005. It has a large database with species descriptions, photographs and other relevant information that help in the identification of plants.

There is an extensive number of plant morphology terms in BFT, approximately $45 \%$ of which are adjectives (501/1111). This is atypical: adjectival terms are not unfamiliar in other disciplines, but such a large proportion is rare. They have usually been considered marginal and replaced by property names or modifiers of noun phrases in terminological dictionaries. In plant morphology, as I will argue in this article, this is neither sensible nor possible; adjectives must be retained as adjectives.

This study offers new information on adjectival terms in general, and on adjectives of plant morphology in particular. Botany is perhaps quite special among the special languages because its terminology has a long tradition and the international nomenclature of plants is very established. Botanical adjectives are, however, distinct from plants' names, and they are not standardized. I think that many of my results can 
apply to other disciplines or special languages as well. Of course we must take into account that adjectives in plant morphology may have features that cannot be generalized for all adjectives, also in other branches of botany. For comparison, I present adjectives in plant ecology, which comprise $21 \%$ of all the terms in plant ecology (in BFT 108/503).

In BFT and particularly in its botanical pilot project, we have had to consider the presentation and definition of adjective terms. Since the terminological database works by crowdsourcing and is openly accessible, it is important to find simple practices and clear instructions for presenting terminological entries. The structures for defining adjectives offered in the ISO 704 -standard (e. g. being, occurring, of) are not natural in Finnish and their close equivalents are fairly clumsy (kuvaa x:ää, joka 'describes $\mathrm{x}$, that'; sellainen $x$, joka 'such $\mathrm{x}$, that'; $x$ :stä, joka 'from $\mathrm{x}$, that'). Many of these alternatives also contradict the substitution principle. Traditionally in Finnish-language botanical books adjectives have been defined directly by a noun (or nouns) that refers to an object, as if the term were a noun (e.g. adjective erillinen [free] can be defined as "a petal, sepal, carpel or stamen that is not united with other organs"). Lemmas have rarely been proposed as $\mathrm{A}+\mathrm{N}$ phrases, which is understandable simply because, on the one hand, adjectives never occur as a part of NP in the descriptive texts of floras and, on the other hand, because one adjective can describe various structures and it would generate several lemmas (e.g. free petal, free sepal and so on).

I analyse the semantics and use of adjectives in my material in order to highlight the specific nature of adjective terms. One of my objectives is to facilitate identifying adjectives as terms, which may be difficult, for example, for translators. At the same time I consider the basic principles of the theory of terminology and the relationship 
between adjective terms and referents. I explain the definition methods used in botanical texts, and I analyse the differences and resemblances between adjectives and nouns as terms. On the basis of this analysis I present some possibilities for definition that are often used but possibly considered incorrect, and are thus missing from the principles of terminology work. I also use semantic reasons to argue why adjective terms of plant morphology should not be changed to property names or modifiers of noun phrases. Instead, they should appear as adjectives in terminologies and glossaries.

2. Adjectives as a part of speech and as terms

\subsection{Part of speech}

Many studies have noted that the border between adjectives and nouns fluctuates, and is different in different languages (see Wierzbicka 1986, Dixon 2004, VISK § 603). Arguments for separating them into two classes have also been found in semantics (in Finnish Setälä 1910, 44-45) and inflexion (Penttilä 1963, 498-500; L. Hakulinen 1979, 71). Their syntactical features also differentiate them from each other (Lyons 1977, 448).

According to Dixon (1977, 19-20), some languages have no adjectives at all, or adjectives constitute only a small and unproductive class. If the category is absent, adjectival concepts are expressed, for example, by verbs or nouns; these classes occur in every language. Later, Dixon retracted his words partially (Dixon 2004: 2-3). Recognizing adjectives, however, is not always self-evident, and it can be different in different languages. 
The inflexion of adjectives and nouns in Finnish is mainly convergent. In addition, new adjectives and nouns can be formed with the same suffixes (e.g., $-k k A,-k A s$, $-v A^{4}$ ), adjectives can be used as nouns, and nouns can be compared in certain situations. Lexicalized participles can also be used similarly to adjectives and nouns (e.g., mahtava 'awesome' < mahtaa 'may' + PARTICIPLE SUFFIX -vA; etsi-vä 'sleuth' < etsiä 'to look for' + PARTICIPLE SUFFIX - vA). Sometimes Finnish adjectives have been counted as nouns because of very similar inflection (Thompson 1989, 249). They, however, have semantic features that mark them off from nouns, and they reflect also on inflection (Pajunen 1994, 531). Nouns, for example, are inflected more than adjectives, and thus exhibit more morphological differences than adjectives (Pajunen 1994, 533). The possessive suffix, for example, can not be added to an adjective.

Comparing languages brings out interesting features. Similar meanings may be encoded in one language in a noun, in another language in an adjective (corresponding to the adjectives male and female in English, Russian only has the nouns samec and samka). In the same language adjectives and nouns can sometimes be used synonymously (e.g., round - circle, stupid - fool, holy - saint), and antonyms can differ in their part of speech status (grown up - child) (Wierzbicka 1986, 354).

In prototype thinking the insufficiency of semantic separation is not a problem. According to Lyons (1977) only the cores of adjective and noun classes can be separated from each other, while according to Wierzbicka (1986) all nouns, whether cores or not, differ from adjectives systematically and mainly predictably because they cate-

\footnotetext{
${ }^{4}$ Upper case in the suffix contains two allomorphs (e.g. $A=a / \ddot{a}, U=u / y$ ) that can be used depending to the quality of vowels in the stem.
} 
gorize (Wierzbicka 1986, 356-358). Thus adjectives also classify in addition to characterizing and identifying (Warren 1984, 95-101). Then they occur mainly as modifiers but sometimes also as predicatives (Warren 1984; Dixon 1999, 2-3).

\subsection{Relative and absolute adjectives}

Adjectives that are gradable and have degrees of comparison (big: bigger) are called relative. They can also have intensity modifiers (quite big, very big). They describe a perceptible or measurable feature, and because of this they are dependent on the referent of a head noun for meaning (small bear vs. big fly). They often have an antonym (big : small, tall : short), and an adjective that expresses the bigger degree of character is typically the neutral representative of the whole scale. (VISK 2008, § 605; Kennedy 1999, xiii-Xviii. $)^{5}$

Relative adjectives in Finnish are typically simplexes (or other morphologically unmotivated adjectives) (e.g. Jussila 1973: 402) and they occur equally as predicatives or as modifiers in sentences. According to Hakanen (1973, 20-21), the basic function of adjectives is expressing relations: relative adjectives are typical representatives of the category. Their meaning is formed in context, when the members of the relationship are known.

Adjectives that describe the features that the referents have or have not (living, commercial, wooden, prehistoric) are called absolute. They occur mainly in an attributive status, rarely in a predicative, and they categorize the referents that they modify.

\footnotetext{
${ }^{5}$ Kennedy uses the terms (1999) gradable and non-gradable, which refer to inflection with or without degrees of comparison. Designations relative and absolute refer more directly to semantics.
} 
They do not usually have intensity modifiers, they are non-gradable and have no degrees $^{6}$. They are independent of the referent of a head noun for meaning. They typically are denominal derivatives that express material, temporal or local origin, term or duration, association or membership in something.

Independence from the context is a characteristic of absolute adjectives. They form non-gradable antonym pairs with two members (living : lifeless, commercial : uncommercial) or a series where each member excludes the others (wooden-metallicplastic). (See Hakanen 1973, 20-21; Hakulinen - Karlsson 1979, 78-79; Warren 1984; Dixon 1999, 2-3; VISK 2008, § 606.) Because of this they need support from other adjectives, for example, from the series in question, for defining their meaning.

\subsection{Adjectives of plant morphology}

Adjective terms of plant morphology are always absolute. They are independent of the referent that is described for meaning, they are categorising and they form antonym pairs or series where each member excludes the others. Their meaning is clearly restricted. Also, when relative adjectives from the general language have been used as terms of plant morphology (e.g., elliptic, ovate, orbicular), their meaning is absolute in the special language context. They can sometimes have intensity modifiers such as relative adjectives, but the modifier is then a part of a term (e.g., broadly ovate) and the complex phrase represents a concept that is different from its head word.

Adjectives are needed in botany, particularly in plant systematics, when a description of the structures of plants is necessary for the identification and separation of

\footnotetext{
${ }^{6}$ Theoretically both syntactic operations would be possible; the difference between absolute and relative adjectives is basically semantic (Kennedy 1999, xvi, 41, 56).
} 
the species. Thus their primary function is categorising; the adjective is not meant to characterize the plant but to indicate what botanical taxon it belongs to.

The structure of adjectives in plant morphology in the Finnish language can be simplex, derivative, compound, or complex phrases. The structural type of terms may be changed when they have been translated to Finnish from, for example, Latin, Swedish or English. Terms in the participle may be changed to adjectives or vice versa, and the compound may be changed to a derivative or vice versa. ${ }^{7}$

Botanical terms in Finnish are from the $19^{\text {th }}$ century, when the use of the Finnish language expanded to all fields of Finnish society. Term formation was conducted in many directions. For example, in the first Finnish botanical vocabulary from 1858 (and in the first flora in 1860) the Finnish language and its traditions strongly influenced the naming of concepts; on the other hand, foreign source languages and the traditions of the discipline's term formation can also be seen in the new formations (Pitkänen-Heikkilä 2013). The structural and semantic motivation of the terms has thus originated from these three backgrounds.

The existence of certain "basic shapes" is typical of adjectives of plant morphology. Various co-ordinate or opposite shapes can also exist. The basic shapes of a leaf blade have been named in Finnish, for instance, using very similar terms that represent co-ordinate concepts such as soikea, suikea, puikea and pyöreä (Engl. elliptic, lanceolate, ovate, orbicular). Their subordinate concepts have compound names such as kapeansoikea, leveänsoikea, kapeansuikea, leveänpuikea, vastapuikea and pitkänpyöreä (narrowly elliptic, broadly elliptic, narrowly lanceolate, broadly ovate, obovate, oblong). (For ostensive definitions, see Illustration 1.)

\footnotetext{
${ }^{7}$ For the origin of Finnish-language botanical terminology, see Pitkänen 2008.
} 
Illustration 1. Puikea [Engl. ovate] and vastapuikea [obovate]. (In RK1998.)

\subsection{Resemblances between adjective and noun terms}

Because they categorise, adjectives in botany are particularly close to nouns; noun and adjective terms can even act in the same function in texts of Floras. For example, nouns and adjectives can be presented as co-ordinate concepts of each other in the definition patterns of Floras (e.g. RK1998: "kukinto norkko tai sarjamainen" [inflorescence catkin or umbel-like]).

The difference between adjectives and nouns is very clear if an adjective is derivative; that is, if an adjective is derived from a noun and exists, for example, in possessive use (e.g. the plant structure can be tähtikarvainen [tähti 'star' + karva 'hair' + ADJ. SUFFIX -inen, Engl. stellate], vs. term tähtikarva [stellate hair]) or if the term is a quality adjective (floral structure can be huulimainen [huuli 'lip' + ADJ. SUFFIX -mAinen, lipped], vs. term huuli [lip]).

The same derivative patterns can, however, also contain terms whose base words do not act as a term (especially inen- and mAinen-derivatives). Plant morphology adjectives are mainly like these. For example, the base word of the derivative herttamainen (hertta 'heart' + ADJ. SUFFIX -mAinen, Engl. cordate), and compound or complex phrase in the background of the compound term kourasuoninen (koura 'hand' + suoni 'vein' + ADJ. SUFFIX -inen, Engl. palmately veined) does not belong to the terminology of this special language. Such designations emphasize the naming of a certain type plant structure: the certain type of leaf shape is named, for example, by the 
adjective herttamainen [cordate]. Other names of leaf types include pitkulainen (Engl. elongate), pitkänpyöreä (oblong), pyörë̈ (lit. 'round', orbicular), soikea (elliptic) and suikea (lanceolate), which can also be defined with an ostensive definition (see Illustration 2). In the general language the same adjectives are approximate and relative in meaning, but the relativeness of terms in botany is based on the gradation that has been abstracted from the variation occurring in nature.

The position of concepts in the concept system, in which the meaning of the terms is limited and made concrete by co-ordinate concepts, is essential in the definition of adjectival terms in plant morphology (and also in the definition of other concepts). The terms that represent the co-ordinate concepts of an adjective term name all other possible characteristics that belong to the extension of the superordinate concept. Fundamentally it is a question of using terms in a context in which other possible terms are known; the terms that name co-ordinate concepts are members of a series in which each member excludes the others.

Illustration 2. Ostensive definition of the adjectives naming leaf shapes in RK1998 (in English terminology: elongate, oblong, orbicular, elliptic, lanceolate).

The closeness of adjective and noun terms in plant morphology is also evident when nouns are descriptive; for example, in metaphors. Metaphoric terms include terms that name a plant's petals, such as huuli, purje and siivet (in English botany: lip, standard and wings). Terms in Finnish plant morphology also contain plenty of descriptive expressive vocabulary (such as designations of inflorescence huiskilo [Engl. panicle 'a 
compound determinate inflorescence with numerous branches from the main axis below its top flower'] $\leftarrow$ huiskia 'to windmill, to hash').

In plant ecology some adjectives and nouns are so synonymous that they can be used alternatively for the same concept in the same context. A comparison of the equivalence of concepts in other languages shows that certain nouns may repeatedly have adjectival equivalents or vice versa in dictionaries. Similarly, a concept in one language may have both adjectival and nominal designations. Synonymous terms in different languages have been listed below; they are designations of the same concept, but in one language the term is a noun, in the other an adjective:

Fin. n. kalkinvaatija [calcium-require+AGENT SUFFIX -jA], Engl. s. basicole, a. basicolous, Swe. a. kalkkrävande [calcium-require-PARTICIPLE] 'of plants confined to ground with a high $\mathrm{pH}^{\prime}$

Fin. a. endeeminen, n. endeemi, Engl. a. endemic, Swe. n. endem, a. endemisk 'of a taxon having its natural distribution restricted to the geographic area in question'

In addition, taxonomic units of plant systematics are often nouns in adjectival form (yksisirkkaiset 'one cotyledon' + iset [adjectival suffix -inen in plural], Monocotyledonae; koppisiemeniset, Angiospermae), but they can be used as adjectives as well ("What are the examples of monocotyledon herbal plants?").

Adjective and noun terms are particularly similar with each other in plant morphology. However, we do not have any actual reason to change adjectives to nouns by derivation (property names, e.g. elongate $\rightarrow$ elongateness, elliptic $\rightarrow$ ellipticity). Very interesting questions in this respect are: What are properties conceptually like? Where are they placed in the concept system? How are they named - with an adjective or a 
noun? What is the relation between adjective terms and property names, and can adjectives always be changed to property names?

\subsubsection{Adjectives vs. property names}

In the narrative texts of my material (in descriptions of species and definition patterns in Floras) property names do not appear at all. This is the reason why property names seem intuitively odd botanically (even if they occurred in the general language). Such property names would be, for example, "sepivyys" (*amplexicaulness), "puikeus" (*ovateness), "herttamaisuus" (*cordateness) and "parijakoisuus" (*pinnatifidness), derived with the suffix $-(U) U s$ from the plant morphology terms sepivä (Engl. amplexicaul, clasping), puikea (ovate), herttamainen (cordate) and parijakoinen (pinnatifid). Why do they not exist in running texts? The reason is that it is not essential in botany to consider, for example, "amplexicaulness" but it is important to differentiate an "amplexicaul" leaf from a "decurrent" leaf. Or there is no reason to examine the grade of "ovateness" but it is important to recognize this leaf shape from other shapes. It is crucial to point out the structures and properties of plants that separate one species from other species: the most important function of describing species is the classification it enables. The corresponding property names again change terms conceptually: they entail relativeness and gradableness.

According to VISK ( $§ 175)$, Finnish noun derivatives with the suffix $-(U) U s$ are very productive, and they can be formed from any adjective or participle. Semantically this derivative type (property names) has been studied very little. If property names are formed from adjectives of plant morphology, the concept seems to become 
more gradable, as though the property name characterising the referent caused speculation over the grade of property or over its existence (possibly also speculation that the characterised referent does not have this property at all).

According to VISK, the property name presents "in the form of a noun, that is, as a concept, the property described by the base adjective". In regard to pienuus 'smallness', for example, VISK gives the definition "se, että on pieni" 'the state of being small' (VISK $§ 175)$. Plant ecology term like vesihakuisuus (hydrophilicity) would then mean 'the state of being hydrophilic', alkuperäisyys (indigenousness) 'the state of being indigenous' and plant morphology term puikeus (ovateness) 'the state of being ovate'. Could these derivatives, however, include the possibility that the described referent may not be very (or in the least) hydrophilic, completely indigenous or ovate? Does the content of the concept make it more relative and abstract if the designation has been changed from the adjective to the property name? The adjectives vesihakuinen (Engl. hydrophilic), alkuperäinen (indigenous) and puikea (ovate) state that the described referent has these clearly defined properties, which differ from other properties, while the property names vesihakuisuus 'hydrophilicity', alkuperäisyys 'indigenousness' and puikeus 'ovateness' do not take a clear stand on the existence or grade of the property.

When the adjective is the other of two members of an antonym pair, the ends of the scale are, in fact, the opposite grades of one property. Thus, antonym pairs such as erilliseminen-yhdiseminen (Engl. apocarpous-syncarpous), ruodillinen-ruoditon (petiolate 'with leaf-stalk'-apetiolate 'without leaf-stalk'), steriili-fertiili (sterile-fertile) could be described by property names (e.g. apocarpy, petiolateness, sterility). My 
question is: do these property names include the meanings of opposite concepts (e.g. suncarpy, apetiolateness, fertility) or do they need their own terms?

BS2001, which uses property names as headwords, contains, for example, the antonyms aikaisemisyys and aikaisheteisyys:

aikaisemisyys [early+pistil+ADJ.SUFFIX -inen + PROPERTY NAME SUFFIX - $(U) U s]$, Engl. protogyny aikaisheteisyys [early+stamen+ADJ.SUFFIX -inen + PROPERTY NAME SUFFIX - $(U) U s]$, Engl. protandry

In contrast, FN2004 has adjectives protogynous and protandrous, and defines them as follows:

protogynous $=$ applied to a flower shedding its pollen after the stigma has ceased to be receptive protandrous $=$ applied to a flower shedding its pollen before the stigma is receptive

If the terms are used as property names they are describing phenomena that are relative, but in adjectival use, it is question of characterising plants and the meaning is absolute - in this situation there is no need for property names. Those property names would be semantically quite odd in plant descriptions because the concepts are not gradable - when separate a plant from the other plants, it is not the grade of "emisyys" ('pistil-ness; the fact that there are pistils') or "heteisyys" ('stamen-ness; the fact that there are stamens') that is essential but is "pistilness" earlier than "stamenness" (in other words, pistils grow up before stamens), or vice versa.

Categorising adjective terms that are members of a series in which one member excludes the others, can not be changed to property names, because the concepts do not express the grade of a property (on puikea 'is ovate' vs. *ei ole puikea 'is not 
ovate'); instead of negation the other alternative should offer some of the other members of the series. When an adjective is a member of a series in which one member excludes the others (puikea-suikea-soikea [Engl. ovate-lanceolate-elliptic]), the formation of antonyms with negation is not reasonable. Property names seem to be linked more naturally to adjectives with an antonym than to those without one. As a result, it is impossible to automatically change all adjective terms to nouns (by derivation) in order to facilitate definitions in terminological dictionaries. Adjectives in plant morphology are typically members of such series.

This must be seen as a question of specific semantics or the conceptual structure of terms; morphologically it is possible to form property names from any adjective or participle, in Finnish from some nouns as well (e.g., äiti-ys 'maternity' < äiti 'mother', opettaj-uus < opettaja 'teacher') (VISK 2008, § 175). The series described, however, are not as clear in the general language as they are in special languages, and testing with the help of intuition may not be possible with adjectives in the general language. At the same time, members of the series of absolute adjectives, given as examples in VISK (§ 606) puinen-metallinen-muovinen ('wooden-metallic-plastic'), belong to the same series. As property names (puisuus, metallisuus and muovisuus 'woodness, metallicness, plasticness'), however, such a series is lost, and it is compensated for with relativity: it is no longer essential to separate one material from other materials, but to focus on the relative content of material in each one. A closer study using data from the general language would be interesting.

The definition of property names may ostensibly be easier than the definition of adjectives, but in terms of understanding, the result is not necessarily conclusive. For 
example, the antonym pair yhtäläisitiöisyys (homospory) and erilaisitiöisyys (heterospory) are property names which lose their connection when defined in BS2001. Speaking about "similarity" or "situation" does not clarify the meaning of concepts:

yhtäläisitiöisyys = kasvin itiöiden samanlaisuus

[homospory similarity of spores of plants]

erilaisitiöisyys $=$ tilanne, jossa kasvilla on kahdenlaisia itiöitä, isoitiöitä eli makrosporeja ja pikkuitiöitä eli mikrosporeja

[heterospory situation where a plant has two types of spores, macrospores and microspores]

In the BFT the concepts have been presented as adjectives:

yhtäläisitiöinen = kasvi, jonka kaikki itiöt ovat keskenään samanlaisia

[homosporous a plant whose spores are all similar to each other]

erilaisitiöinen $=$ kasvi, jolla on sekä iso- että pikkuitiöitä

[heterosporous a plant which has both macrospores and microspores]

It does not seem to be semantically natural to form property names from the adjective terms in this special language. This is especially true of descriptive, absolute adjectives forming a series in a concept system where one member excludes the others. In addition, it is not clear that it would be advisable to define the property name instead of the definition of the adjectival term.

Without a knowledge of the concept system it is impossible to see the connection between a concept and the series it belongs to. It follows from this that without a 
good knowledge of a special field and its language it is impossible to form noun derivatives from its adjectives. Adjective terms often seem relative because of their form, but they may be absolute and members of a series where one member excludes the other. For example, the words puikea and soikea (Engl. ovate, elliptic) are relative and do not belong to such a series in the general language, but in botany they are absolute adjectives and important members of such series.

Adjective terms of disciplines other than botany are not necessarily categorising. In linguistics, for example, many adjectives (e.g., affective) are relative and can be changed to property names (affectivity) because the amount or grade of property is essential in the intension of concepts; thus adjectives in this case are relative from the start. Certain property names (as also action names) are particularly typical in scientific texts ${ }^{8}$. Also, prototype- and continuum-thinking in linguistics has connections with relativity and gradability. For example, the terms reflexive and laryngeal occur as absolute adjectives. When they form a series where one member excludes the others, it does not make sense to change them to property names (reflexive vs. deictic possessive suffix; laryngeal vs. pharyngeal phoneme). When the phoneme is laryngeal 'arising in voice box', there is no need to be concerned with "laryngeal-ness" or the relativity of the phoneme's property, but to separate the laryngeal phoneme, for example, from the pharyngeal 'arising in throat' phoneme.

\subsubsection{Adjectives vs. noun phrases}

\footnotetext{
${ }^{8}$ According to Halliday (2001 [1992]) nominalization is typical of scientific language; VISK (VISK $\S$ 175) remarks that certain $-U(U) s$-suffixes are particularly typical in scientific texts (e.g., tekstiys ['textness' ], parafraasius ['paraphrase-ness').
} 
Syntactically the typical function of adjectives is either attributive or predicative. Adjective terms occur in the predicative state without a copula in descriptions of species and in definition formulas in Floras. This is an old tradition in botany. The adjectival structures of the oldest, Latin descriptions of species could, however, also be read as post-modifiers of nouns. For example, Linné's Flora Svecica (1745) describes species in the following way:

Anemone feminibus acutis, foliolis incifis, caule unifloro.

Anemone nemorosa, flore majore.

(Linné 1745: 164.)

Flore majore can be read as either NP ('big flowers') or as a predicative structure without a copula ('flowers [are] big', flore majore [sunt]). The latter practice has been established in other languages and is functional as translated because it highlights the plants' structures and their features as a topic. The predicative structure was used, for example, in Flora Europaeia in 1964:

Paeonia L. - - Leaves large, simply biternate, or further divided. Flowers 6-14 cm in diameter; petals white, pink or red. Stamens numerous. --

(Tutin et al. 1964: 243.)

The adjective following the noun can also be considered its post-modifier. In Finnish, however, using the partitive case in the plurals confirms the predicative interpretation: it is only possible, because as a predicative an adjective is in the partitive case, and as 
a modifier it is in the nominative. Finnish descriptions of species always have adjectives in predicative state. For example, in RK1998 they are like the following:

Lotus - Maitteet. - - Lehdet päätöparisia, 2-parisia, alemman parin lehdykät korvakemaisia - - muut lehdykät vastapuikeita - - korvakkeet surkastuneita.

[leaves imparipinnate-PL.PARTIT, two-pinnate-PL.PARTIT, lower pear's leaflets stipulate-PL.PARTIT - other leaflets obovate-PL.PARTIT - - stipules abortive-PL.PARTIT]

Adjectives occur no as the part of nominal phrase in my material from the descriptions of species in Finnish Floras. For example, OKT2005 (translated from English by Arto Kurtto) and E-learning environment Pinkka also use the partitive case and so their adjectives are predicative. Pinkka also has predicatives in complete sentences with a copula: varsi on pysty [the stem is erect].

Although absolute adjectives typically occur as modifiers in the general language, I argue that the classifying adjectives of botany should not be presented as the modifiers of nouns in the head words of terminological dictionaries but lemmas should be adjectives (erect instead of erect stem). The reason is that adjectives never occur in a nominal phrase but as predicatives in descriptions of species. The information structure of the descriptive texts of species is clear: the various structures of plants and their parts and characteristics exist as the essential information. Based on these, species can be distinguished from other species.

3. Definition of adjective terms in practice

3.1. Definition in the history of botany 
Elias Lönnrot, the writer of the first Finnish Flora, defines the adjective terms of plant morphology in the same way as nouns: with the help of superordinate concepts that are nouns. For example, lanttopäinen (Engl. emarginate) "a plant with a low, hollow notch in the head"; nirhalaitainen (Engl. dentate) "a leaf margin with a small, round notch in between small sharp teeth" (definitions translated from Finnish) (Pitkänen 2008). This method was also used in Finnish later, for example, in the small vocabulary of 300 terms in RK1998. Similar definitions of adjectives exist in botanical books of other languages as well.

In the English-language FN2004, the adjective terms of ecology have been defined by nouns, but terms of morphology have not (e.g. ecological annual = $\underline{\text { a plant }}$ which completes its life cycle within a year; $\mathrm{cf}$. morphologic acuminate $=$ narrowing gradually, with more or less concave sides, to a point). Such definitions are, thus, not extremely exceptional in languages other than Finnish either, although this practice exists more in older Floras.

John Lindley's Introduction to Botany (1848), for example, has vocabulary in which adjective terms have typically been defined with another adjective or verb structure (e.g. having, forming, -ed). A referent that the adjective characterises, however, has also appeared in the definition:

globose $($ globosus $)=$ forming nearly a true sphere; as the fruit of Ligustrum, many seeds \& $c$.

depressed (depressus) $=$ flattened vertically; as the root of a Turnip

(Lindley 1848, 347-348.) 
Some adjective terms have, however, been defined directly through the referent described, with a noun as the head word of the definition:

wheel-shaped $($ rotatus $)=$ a calyx or corolla, or other organ, of which the tuve is very short, and the segments spreading; as the corolla of Veronica

hooded (cucullatus) = a plane body, the apex or sides of which are curved inwards, so as to resemble the point of a slipper, or a hood; as the leaves of Pelargonium cucullatum, the spatha of Arum, the labellum of Pharus.

(Lindley 1848, 351, 353.)

Methods of definition naturally differ between languages that are morphologically different (this is noted also in ISO 704:2009, 25). For example, Lönnrot's source books in Swedish or German do not define adjectives by nouns. Instead, the definitions begins with the words när, då, som or wenn, which give some temporal dimension to the meaning of the terms. For example, the definitions of adjectives by Swedish botanist J. Arrhenius in Elementarkurs $i$ Botaniken ${ }^{9}$ begin with "då" or "när"; conjunctions such as "då" and "som" are also used in the definitions of nouns:

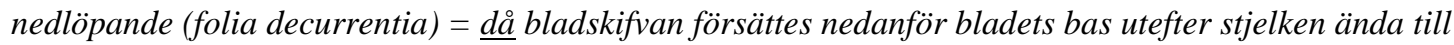
nästföljande nedre blad.

[decurrent ('running down') = since/then/when the leaf blade continues below to the leaf base along the stem to the inferior leaf]

${ }^{9}$ Third, revised edition 1857. Lönnrot used the 1st edition from 1845. 


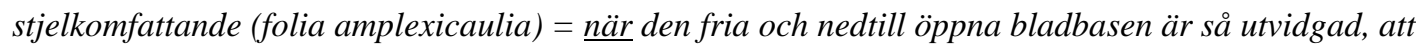
den helt och hållet omfattar stjelken.

[amplexicaul, clasping $=$ when the free and lower open leaf base is so extended that it surrounds the stem completely]

(Arrhenius 1857, 52.)

rotblad $($ folia radicalia $)=$ som utveckla sig från det nedersta, vid rothalsen varande stamämnet . [root leaf $=$ that grows from the bottom, from the stem near the root neck]

stjelkblad $($ folia caulina $)=$ då de äro fästade på stjelken.

[stem leaf $=$ when they are fastened on the stem $]$

(Arrhenius 1857, 48.)

Bischoff's terminology from 1833 (Handbuch der botanischen Terminologie und Systemkunde) was also one of Lönnrot's source books. Its German-language definitions of adjectives typically begin with "wenn":

geschieden $($ segregatus - séparé $)=$ wenn nahe beisammenstehende Theile, durch besondere Hüllen von einander getrennt sind.

[separate $=$ when close organs diverge from each other without reason $]$

eingedrückt (retusus - obtus $)=$ wenn die Spike eine seichte Bucht bildet

[retuse ('to make blunt') $=$ when a spine forms a low cove $]$

(Bischoff 1833, 69, 80.)

In BFT, where work is based on voluntariness and crowdsourcing, the aim has been to find simple methods for the formation of definitions. Structures or words that refer di- 
rectly to the word being defined (e.g. "kuvaa lehteä, joka" 'describes a leaf that'; "sellainen lehti, joka" 'such a leaf that') can make the definition clumsy. Botanists in the BFT botanical expert group also tend to define plant morphology adjectives with nouns naming the plant structure being described, and this principle has been followed during the whole botanical pilot project. In terminological entries of BFT, however, the concept relation between the adjective term and noun given in the definition is formulated as the relation between the "property" and "bearer of the property" (not between the "subordinate concept" and "superordinate concept"). ${ }^{10}$

\subsection{Definitions of adjectives in present day Floras}

Several methods to define adjective terms in Finnish have been used over the last decades. Property names or noun phrases with adjective modifiers do not exist at all in the Flora vocabularies (RK1998, FN2004, OKT2005). Instead, certain botanical adjectives have consistently been replaced by noun phrases or property names in BS2001, which is a dictionary and does not include descriptions of species.

The following lists present different types of definitions of adjective terms in the source books used at the BFT (RK1998, BS2001, FN2004, OKT2005). Flora Nordica's definitions are in English; the other definitions have been glossed from Finnish and are presented in square brackets.

A) Definitions in which an adjective is defined with another adjective

\footnotetext{
${ }^{10}$ I want to emphasize that the terminological status of adjectives is not dependent on their participation as modifiers in NPs, although at the same time, I agree that "bearer of the property", which would be the head word in NP, is a very essential member in the definition of adjective terms.
} 
harsu $($ Engl. lax $)=$ harva [loose] $($ RK1998)

tasasoukka $($ linear $)=$ kapea ja suoralaitainen $[$ narrow and straight-margin+ADJ.SUFFIX] (OKT2005)

torvimainen $($ tubular $)=$ tube-like $($ cylindrical and hollow, with open ends $)($ FN2004)

An ecological term:

mesotrofinen, keskiravinteinen (mesotrophic) $=$ medium rich in nutrients $($ FN2004)

B) Definitions in which an adjective is defined with a participle or an infinitive

siirottava $($ patent $)=$ suoraan ulospäin suuntautuva [strictly upwards projected] $($ RK1998)

abaksiaalinen $($ abaxial $)=$ rakenteen rungosta tai keskirangasta poispäin suuntautunut [turned away from an axis] (BS2001)

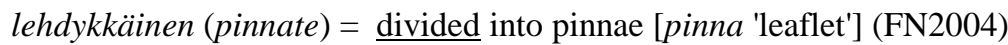

halkihaarainen $($ dichotomous $)=$ forking into two equal branches (FN2004)

An ecological term:

edafinen $($ edaphic $)=$ maaperään liittyvä, maaperässä elävä [soil related, living in soil] (BS2001)

C) Definitions in which an adjective is defined with a noun (expresses a referent that the adjective characterises) 
epämukainen $($ asymmetric $)=\underline{\text { kasvinosa, }}$ jota ei voida jakaa kahteen samanlaiseen osaan [a plant's part that cannot be divided into two similar parts] (RK1998)

neuvoton $($ sterile $)=\underline{\text { kukka}}$, josta puuttuvat sekä heteet että emit [a flower without carpels or stamens] (RK1998)

sepivä $($ amplexicaul $)=\underline{\text { lehti }}$, jonka lavan tyvi ympäröi vartta [a leaf the base of whose leaf blade clasps the stem] (OKT2005)

\section{Ecology terms:}

$y$ ksivuotinen $($ annual $)=\underline{\text { a plant }}$ which completes its life cycle within a year $($ FN2004 $)$

allopatrinen $($ allopatric $)=\underline{\text { taxa }}$ with separate distribution areas $(\mathrm{FN} 2004)$

boreonemoraalinen $($ bore-nemoral $)=$ plant-geographic region between the nemoral and the boreal (FN2004)

D) Definitions in which an adjective is defined with the name of a concept it is describing and with a meta-language verb (or preposition in English)

sepivä $($ amplexicaul $)=\underline{\text { kuvaa kasvin lehteä, joka ympäröi vartta lähes kokonaan tai täysin [describes a }}$ leaf of a plant that clasps the stem almost completely or completely] (BS2001)

parijakoinen $($ pinnatifid $)=\underline{\text { of a leaf }}$ cut deeply into lobes, but not to midrib (FN2004) aikaisheteinen $($ protandrous) $=$ applied to a flower shedding its pollen before the stigma is receptive (FN2004)

\section{Ecology terms:}

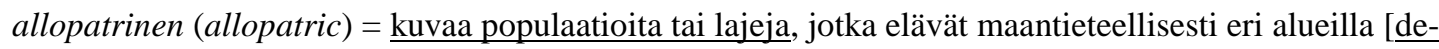
scribes populations or species which live in geographically different areas] (BS2001) 
adventiivinen (adventive $)=\underline{\text { of alien }}$ which was unintentionally brought in by man (FN2004)

E) Definitions in which an adjective is defined as the post modifier of a noun phrase without the head word (the referent it is describing is not mentioned)

abaksiaalinen $($ abaxial $)=$ away from the axis $(\mathrm{FN} 2004)$

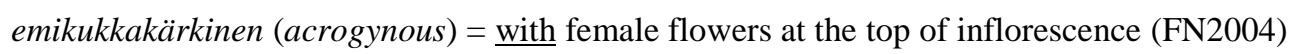

terätön $($ apetalous $)=$ without petals $(\mathrm{FN} 2004)$

RK1998 uses definition types A-C and E, but almost all are type C, in which adjectives have been defined by a noun (kansiluomainen [Engl. circumscissile] = kota, jonka kärkiosa avautuu kansimaisesti [a capsule whose apex opens as a cover of a book]). Types A and B (defined by an adjective or participle) seem to be used when a referent is not characteristic of only one certain plant part (harsu [Engl. sparse]).

In BS2001 noun phrases with adjective modifiers or property names have been expressed as entries instead of adjectives: silposuoninen suonitus (parallel venation); erilaislehtisyys (heterophylly). However, the adjective sepivä (amplexicaul) from plant morphology occurs unexpectedly as an entry without the head word. The chosen policy has been waived in favour of a very old and common adjective that has surely been recognised as a term. Entries that are adjectives have been defined mainly by type D ("describes a plant that..."), the term sepivä (amplexicaul) also. 
FN2004's definitions are types A, B, D and E; with ecology terms also C. Type E has been used only in this English-language vocabulary because the type is not natural in Finnish.

Definitions in OKT2005 are types A-C. In addition, there are definitions that have features of type E and are atypical in other Finnish definitions; the reason for such features is the English language, the source language of the flora:

$\begin{array}{ll}\begin{array}{l}\text { johteinen } \\ \text { ldecurrent }\end{array} & \text { lehtikanta jatkuu siipipalteena varteen } \\ & \text { leaf base proceeds as wing to the stem] } \\ \text { kaksikotinen } & \text { hede- ja emikukat eri yksilöissä } \\ \text { [dioecious } & \text { staminate and pistillate flowers in different individuals] }\end{array}$

\section{Conclusion}

In this article I have examined the place of adjectives in terminologies as well as adjectives terms and their nature in the floral texts that describe and identify species. I suggest that adjectives are independent terms, and their terminological status should not derive, for example, from their participation as modifiers in NPs. Based on investigation of my material of floras, adjectives do not occur as frontal modifiers of nouns in texts that describe plants, but in the predicative state; this is why noun phrases as the entries of terminological dictionaries are artificial. Similarly, property names derived from adjective terms are not possible: they can result in semantically odd, clumsy noun structures that do unjust both to the terms and to the discipline. Property 
names derived from the absolute adjectives of plant morphology do not function because the derivation causes conceptual abstractization and relativity, and the terms do not work according to the original categorising function claimed in plant systematics. The objective of the texts (in descriptions of species) is not to characterise and describe but to identify and classify plants, and exclusionary or alternate characteristics are the criteria of this classification.

A perspective that takes into account the use of adjective terms in special language texts and the practices of definition within the discipline can help in forming both new instructions for terminology work and new standards, and in extending old standards. Marginal terms should not be forced into the mould of the majority: standards must be loose enough for all to fit. Research which is based on empiricism could offer something new to the definition of adverb and verb terms as well. The definition instructions of the ISO-standard are more meagre on those parts of speech than they are on adjectives.

A typical recommendation for defining adjectives is to use another adjective or a participle in the place of a superordinate concept. When defining adjective terms with another adjective or with participles or other verb structures, the naming of the terminologically relevant referent that is being described (the referent from which the adjective predicates the property) may be left undone. Such definitions do not integrate the term into the term system and concept system of a special language. In order to identify the referents, the concept on which the adjective predicates the property should, however, be expressed. This can be done with the elative case (x:stA 'of x'), and in Finnish also with the structure "sellainen x, joka" ['such X that']. Neither of these definition methods have been used in Finnish botanical books, and my study has 
shown that adjectives are still defined like nouns: Finnish definitions of plant morphology terms have been based on the referent described, also in the BFT. This convention can be defended by the closeness of adjective and noun terms in Finnish, and the speciality of adjectives in plant morphology - adjectives name shapes and structural types - and equally by the traditions in botanical writing in Finnish (and also in many other languages). The definitions of adjective terms do not always differ from definitions of noun terms (e.g. kellomainen $=$ teriö, joka muistuttaa muodoltaan kirkonkelloa [campanula 'corona that resembles a church bell in shape']), and because of this, a given noun (corona) is marked as "the bearer of property" in the BFT.

Special concepts that adjective terms represent do not directly represent the referents, but they tell something about them: they express their relations and predicate properties of them. Adjective terms do not name the objects and they do not refer directly to them. Only nouns refer directly to the object. Adjectives, however, still can have an independent state as terms and, in certain subject fields, deserve to be given a self-contained position in terminology. A conceptual relationship between an entity and its characteristic is different than between an entity and its name. The former relationship is a "property relation", which in essence, depending on perception, is either an ownership relation or a part-whole relation between the property and the bearer of property; and the latter is a "generic relation" between sub- and superordinate concepts. They both have their own, important position in terminology theory and practice. 
Material sources

BFT $=$ The Bank of Finnish Terminology in Arts and Sciences. In Web: http://tieteentermipankki.fi

BS2001 = Tirri, Rauno, Juhani Lehtonen, Risto Lemmetyinen, Seppo Pihakaski, and Petter Portin. 2001. Biologian sanakirja. [Dictionary of Biology.] The first copy of revised edition. Helsinki: Otava.

FN2004 = Jonsell, B. (ed.). 2004. Flora Nordica. General Volume. Stockholm.

OKT2005 = Blaamey, Marjorie, and Chistopher Grey-Wilson. 2005. Otavan kasvitieto. [The Illustrated Flora of Britain and Northern Europe.] Translated and adapted into Finnish by Arto Kurtto. Helsinki: Otava.

Pinkka = Lajintuntemuksen oppimisympäristö. [E-Learning Environment. Species identification and Biodiversity studies.] In web: http://helsinki.fi/pinkka

RK1998 = Hämet-Ahti, Leena, Juha Suominen, Tauno Ulvinen, and Pertti Uotila (eds). 1998. Retkeilykasvio. [Field Flora of Finland.] Finnish Museum of Natural History, Botanical Museum. Helsinki.

References

Arrhenius, Johan. 1857 [1845]. Elementarkurs I botaniken. 3. omarb. uppl. Upsala: Wahlström.

Bae, Hee Sook. 2006. Termes adjectivaux en corpus médical coréen: Repérage et désambiguïsation. Terminology 12:1, 19-50. 
Bischoff, Gottlieb Wilhelm. 1833. Handbuch der botanischen Terminologie und Systemkunde. Nürnberg: Verlag von Johann Leonhard Schrag.

Cabre, M. Teresa. 1998. Terminology. Theory, Methods and Applications. Edited by Juan C. Sager. Terminology and Lexicography research and practice 1. Amsterdam/Philadelphia: John Benjamins.

Campos, Araceli Alonso, and Sergi Torner Castells. 2010. "Adjectives and collocations in specialized texts: lexicographical implications." In En proceedings of the XIV Euralex International Congress, ed. Anne Dykstra, and Tanneke Schoonheim, 872-881. Ljouwert: Fryske Akademy.

Casademont, Anne Joan. 2014. On the elements activating the transmission of specialized knowledge in verbs. Terminology 20:1, 92-116.

Castro, Miriam Buendía. 2012. Verb dynamics. Terminology 18:2, 149-166.

Daille, Béatrice. 2001. Qualitative terminology extraction. Identifying relational adjectives. In Recent Advances in Computational Terminology, ed. by Didier Bourigault, Christian Gacquemin, and Marie-Claude L'Homme, 149-166. John Benjamins.

Dixon, R. M. W. 1977. "Where have all the adjectives gone!" Studies in Language I:1: 19-80.

Dixon, R. M. W. 1999. "Adjectives." In Concise Encyclopedia of Grammatical Categories, ed. by Keith Brown, and Jim Miller, 1-7. Elsevier.

Dixon, R. M. W. 2004. "Adjective Classes in Typological Perspective." In Adjective Classes. A Cross-linguistic Typology, ed. by R. M. W. Dixon, and Alexandra Y. Aikhenvald, 1-49. Explorations in linguistic typology; vol. 1. Oxford University Press. 
Faber, Pamela, Pilar León Araúz, Juan Antonio Prieto Velasco, and Arianne Reimerink 2007. "Linking Images and Words: the Description of Specialized Concepts." International Journal of Lexicography 20: 39-65.

Faber, Pamela, Pilar León, and Juan Antonio Prieto 2009. "Semantic Relations, Dynamicity, and Terminological Knowledge Bases." Current Issues in Language Studies 1, 1-23.

Hakanen, Aimo. 1973. Adjektiivien vastakohtasuhteet suomen kielessä. [Antonym relations of adjectives in Finnish.] SKST 311. Helsinki: SKS.

Hakulinen, Auli, and Fred Karlsson. 1979. Nykysuomen lauseoppia. [Syntax of present Finnish.] SKST. 350. Helsinki: SKS.

Hakulinen, Lauri. 1979 [1941, 1946]. Suomen kielen rakenne ja kehitys. [Structure and development of Finnish.] Fourth, revised edition. Helsinki: Otava.

ISO 1087-1: 2000. Terminology work - Vocabulary - Part 1: Theory and application.

ISO 704: 2009. Terminology work - Principles and methods.

Jussila, Raimo. 1973. "Nykysuomen adjektiivien semanttista peruskartoitusta." [Semantic survey of adjectives in the present Finnish.] - Virittäjä 77: 398404.

Kennedy, Christopher. 1999. Projecting the Adjective: the Syntac and Semantics of Gradability and Comparison. Outstanding dissertations in linguistics, edited by Laurence Horn. New York \& London: Garland Publishing, Inc.

L'Homme, Marie-Claude. 1998. Le statut du verbe en langue de spécilité et sa description lexicographique. Cahiers de lexicologie 73:2, 61-84. 
Lindley, John. 1848. Excerpt from "Illustrated dictionary of botanical terms" by John Lindley. With an Introduction by Alice Eastwood. Reprinted 1964, with a Foreword by Joseph J. Graham. Stanford University, Stanford, California, 1964.

Linné, Carolus 1745: Flora Svecica. Exhibens plantas per Regnumsveciae Crescentes, systematice cum differentiis specierum, synonymis autorum, nominibus incolarum, solo locorum, usu pharmacopaeorum. Stockholmiae: Sumtu \& Literis.

Lyons, John. 1977. Semantics. Volume 2. Cambridge University Press: Cambridge.

Pajunen, Anneli. 1994. "Adjektiivi-kategorian universaaliudesta." [Universality of adjective category.] Virittäjä 98: 513-541.

Penttilä, Aarni. 1963. Suomen kielioppi. [Finnish grammar.] 2., revised edition. Porvoo: WSOY.

Pitkänen, Kaarina. 2008. Suomi kasvitieteen kieleksi. Elias Lönnrot termistön kehittäjänä. [The development of botanical Finnish: Elias Lönnrot as the creator of new terminology.] SKST 1164. Helsinki: SKS.

Pitkänen-Heikkilä, Kaarina. 2013. "Term formation in a special language: How do words specify scientific concepts?" In The Semantics of Word Formation and Lexicalization, ed. by Pius ten Hacken, and Claire Thomas, 66-82. Edinburgh University Press.

Ogden, C. K., and I. A. Richards. 1923. Meaning of meaning: Study of The influence of Language upon Thought and of The Science of Symbolism. Longon: Kegan Paul, Trench, Trubner \& Co. 
Robinson, Howard. 2014. "Substance." In The Stanford Encyclopedia of Philosophy (Spring 2014 Edition), ed. by Edward N. Zalta. URL = <http://plato.stanford.edu/archives/spr2014/entries/substance/>.

Sager, Juan C. 1990. A Practical Course in Terminology Processing. Amsterdam/Philadelphia: John Benjamins.

Setälä, E. N. 1910 [1898]. Suomen kielen oppikirja. Äänne- ja sanaoppi. Oppikouluja ja omin päin opiskelua varten. [Finnish grammar, phonology and morphology for students.] Helsinki: Otava.

Suonuuti, Heidi. 2001. Guide to Terminology. Nordterm 8. Finnish Centre for Technical Terminology.

Thompson, Sandra A. 1989. "A Discourse Approach to the Cross-Linguistic Category 'Adjective'". In Linguistic Categorization, ed. by Roberta Corrigan, Fred Eckman, and Michael Noonan, 245-265. Amsterdam: John Benjamins.

Tutin, T. G. et al. (eds.). 1964. Flora Europaeia. Volume 1. Lycopodiaceae to platanaceae. Cambridge: Cambridge univerisy press.

Warren, Beatrice. 1984. Classifying Adjectives. Acta Universitatis Gothoburgensis. Gothenburg studies in English 56. Göteborg, Sweden.

Wierzbicka, Anna. 1986. "What's in a noun? (Or: How do nouns differ in meaning from adjectives?)" - Studies in Language 10(2): 353-389.

VISK = Hakulinen, Auli, Maria Vilkuna, Riitta Korhonen, Vesa Koivisto, Tarja Riitta Heinonen, and Irja Alho. 2004. Ison suomen kieliopin verkkoversio. [Finnish Grammar Database.] Helsinki: Finnish Literature Society. In web: http://scripta.kotus.fi/visk URN:ISBN:978-952-5446-35-7 